\title{
Inhibition of Phospho-MurNAc-pentapeptide Translocase (MraY) by Nucleoside Natural Product Antibiotics, Bacteriophage $\phi X 174$ Lysis Protein E, and Cationic Antibacterial Peptides
}

Timothy D.H. Bugg*, Maria T. Rodolis, Agnes Mihalyi, and Shirin Jamshidi

Department of Chemistry, University of Warwick, Coventry CV4 7AL, U.K.

*Author for correspondence. Email T.D.Bugg@warwick.ac.uk, tel 44-2476-573018

\begin{abstract}
This review covers recent developments in the inhibition of translocase MraY and related phospho-GlcNAc transferases WecA and Tag0, and insight into the inhibition and catalytic mechanism of this class of integral membrane proteins from the structure of Aquifex aeolicus MraY. Recent studies have also identified a protein-protein interaction site in E. coli MraY, that is targeted by bacteriophage $\phi \mathrm{X} 174$ lysis protein $\mathrm{E}$, and also by cationic antimicrobial peptides containing Arg-Trp close to their N- or C-termini.
\end{abstract}

Bacteria contain several cell surface polysaccharides, of which the peptidoglycan cell wall is found in all eubacteria and is essential for maintenance of cell shape and protection against internal osmotic stress. Assembly of the polysaccharide on the cell surface requires an activated carbohydrate substrate that is able to cross the lipid bilayer of the cytoplasmic membrane. For this purpose, a $\mathrm{C}_{55}$ undecaprenyl lipid carrier is used in peptidoglycan biosynthesis, and is also used for other cell surface polymer biosynthetic pathways such as lipopolysaccharide biosynthesis, capsular polysaccharide biosynthesis, and teichoic acid biosynthesis [1]. The first step of these lipid-linked cycles is catalysed by an integral membrane protein, which for peptidoglycan biosynthesis is translocase MraY, which is the target for several natural product antibiotics [2]. This review will describe recent progress in the understanding of the enzymology and structure of this class of enzyme, and its inhibition by natural product and synthetic inhibitors, and by a phage bacteriolytic protein.

\section{Enzymology of MraY and related phospho-sugar transferases}

Translocase MraY catalyses the reversible phosphotransfer reaction between UDPMurNAc-L-Ala- $\gamma$-D-Glu-m-DAP-D-Ala-D-Ala and undecaprenyl phosphate to give undecaprenyl-diphospho-MurNAc-L-Ala- $\gamma$-D-Glu-m-DAP-D-Ala-D-Ala (known as lipid 
intermediate I) and UMP, shown in Figure 1 [3]. It is known to be a 10 transmembrane helix integral membrane protein whose conserved amino acid residues are found on cytoplasmic protein loops [4]. The catalytic mechanism of the enzyme could either involve a one-step phosphotransfer reaction at the $\beta$-phosphate of the UDPMurNAc-pentapeptide substrate, or a two-step mechanism involving attack by an active site nucleophile [3]. There is evidence in favour of the two-step mechanism from isotope exchange studies by Neuhaus and coworkers [5]. There are only three conserved nucleophilic residues in the MraY sequence, three aspartic acid residues Asp-115, Asp-116 and Asp-267 for E. coli MraY. Replacement of each of these residues by Asn gives inactive enzyme [6,7], indicating their essential function in catalysis, and it has been proposed that two Asp residues may be involved in binding of the $\mathrm{Mg}^{2+}$ cofactor, and the other may be a catalytic nucleophile [6].
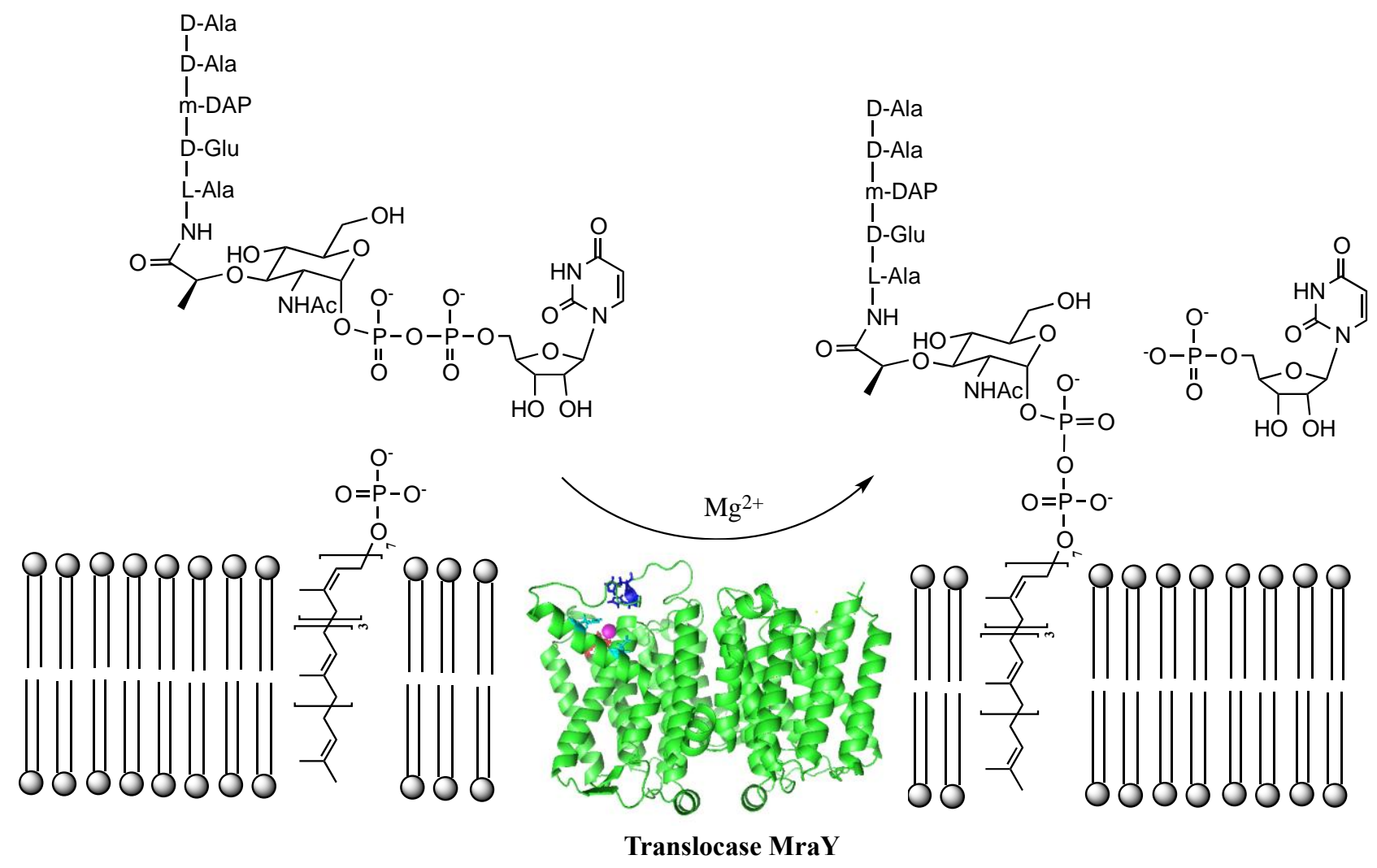

Figure 1. Reaction catalysed by translocase MraY, figure adapted from reference 2.

The crystal structure for Aquifex aeolicus MraY was determined in 2013 by Chung et al. to $3.3 \AA$ A resolution [8]. The enzyme was crystallised as a dimer, with an inter-dimer interface involving helices 10 and 7 (see Figure 2A). Helix 9 is severely bent, and points out 15-20 into the cytoplasmic membrane. At the active site of the enzyme, the three catalytic aspartic acid residues are positioned in the centre of the active site, close to the $\mathrm{Mg}^{2+}$ cofactor, which is ligated to Asp-265 (see Figure 2B). Polar residues Glu-300 and Gln-307 point into the active 
site from bent helix 9, and two histidine residues His-324 and His-325 on a large cytoplasmic loop also point into the active site [8].

We have recently used GOLD molecular docking software to explore the possible binding of the UDPMurNAc-pentapeptide substrate to A. aeolicus MraY. In one low energy conformation, shown in Figure 2C, the substrate diphosphate is bound to the $\mathrm{Mg}^{2+}$ cofactor, which has been proposed as a likely role of the $\mathrm{Mg}^{2+}$ cofactor [6]. The $\mathrm{Mg}^{2+}$ cofactor also contacts the ribofuranose 3'-hydroxyl group and endocyclic oxygen, as well as Asp-265, and the $\beta$-phosphate also interacts with Lys-121. In this structure, Asp-117 is positioned $5.2 \AA$ from the $\beta$-phosphate of the substrate, directly in line with His-324, $8.3 \AA$ away on the other side of the active site, with a cavity in between, where undecaprenyl phosphate could bind. Although docked structures should be interpreted with caution in the absence of experimental data, the spatial alignment of these three groups is interesting, since enzymecatalysed phosphotransfer reactions are known to generally proceed with an in-line geometry, with stabilisation of diphosphates by $\mathrm{Mg}^{2+}$ and an additional Arg or Lys residue [9]. Hence this conformation would be consistent with a two-step mechanism in which Asp-117 attacks the $\beta$-phosphate to generate a phospho-enzyme intermediate, and His-324/His-325 position the phosphate group of undecaprenyl phosphate to carry out a second in-line displacement.

The binding of phosphate groups by nitrogen macrocycles and supramolecular receptors containing 2-6 nitrogen atom donors is certainly precedented [10], and there are literature examples of supramolecular phosphate receptors containing two methylated imidazolium groups that bind the $\mathrm{H}_{2} \mathrm{PO}_{4}^{-}$monoanion, shown in Figure 3 [11,12]. Hence we suggest that His-324/His-325 may sequester the phosphate monoanion of undecaprenyl phosphate, and activate it for nucleophilic attack on the phospho-enzyme intermediate. 

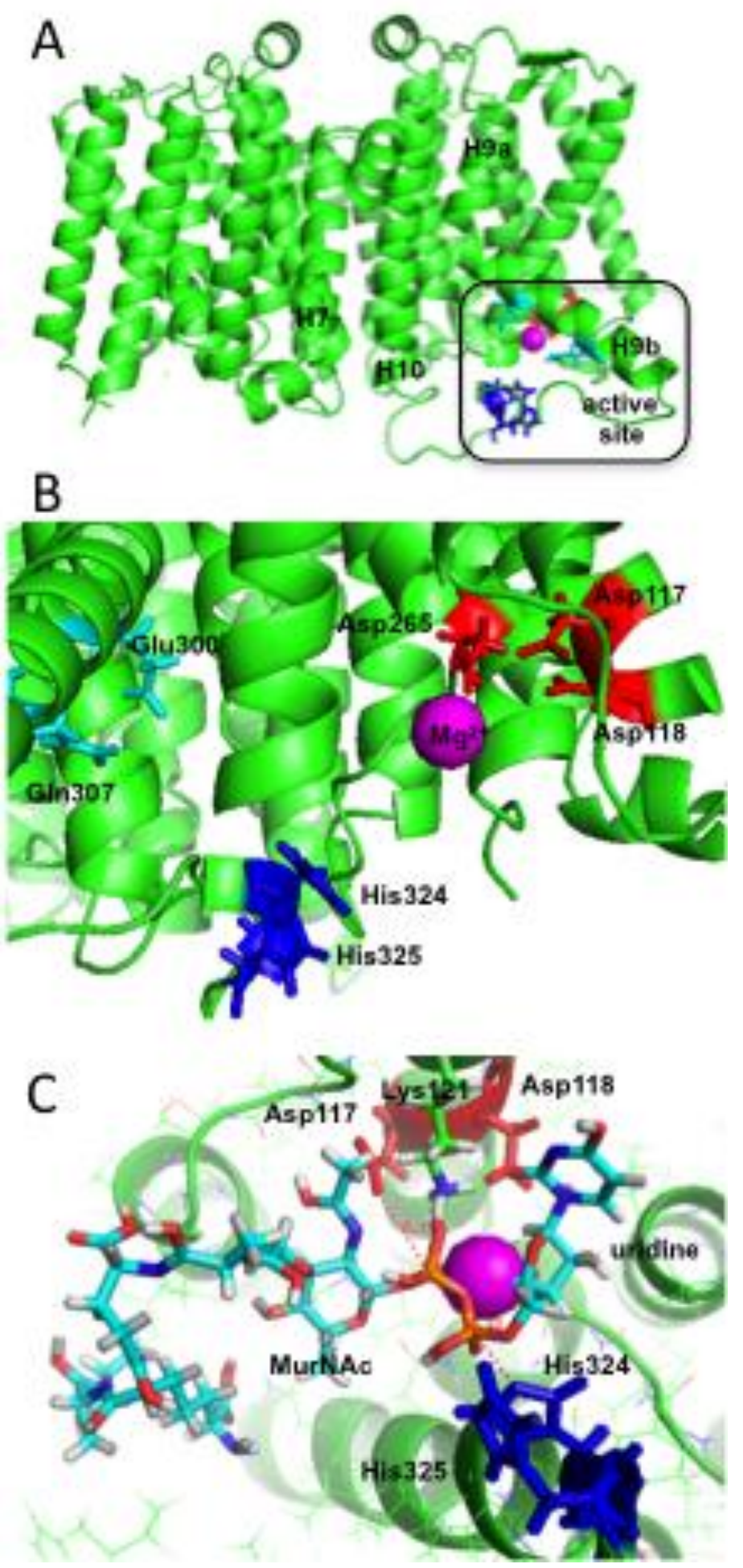

1. Figure 2. Structure of A. aeolicus translocase MraY. A. Protein dimer, with active site on bottom right, labelling helices 7, 9, and 10. B. Active site, with catalytic Asp-117, Asp-118, and Asp-265 in red, $\mathrm{Mg}^{2+}$ cofactor in magenta, His-324 and His-325 in dark blue, and Glu300 and Gln-307 in cyan. C. Structure of A. aeolicus MraY docked with UDPMurNAcpentapeptide, obtained using GOLD molecular docking software [69], after removal of $\mathrm{Ni}^{2+}$ from the active site. Images drawn using PYMOL software [70]. 

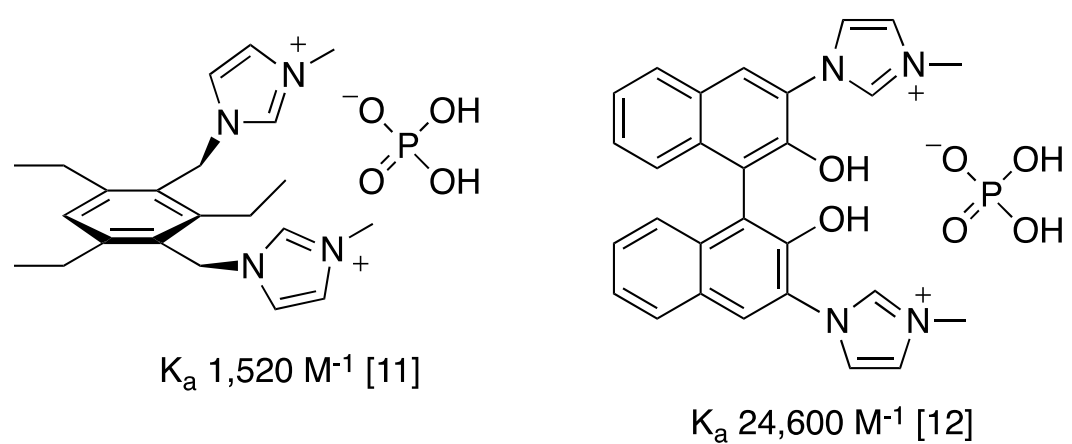

Figure 3. Examples of bis-imidazolium supramolecular receptors for $\mathrm{H}_{2} \mathrm{PO}_{4}{ }^{-}$monoanion, from references 11 and 12 .

The first step of enterobacterial common antigen and 0 -antigen lipopolysaccharide (LPS) biosynthesis in Gram-negative bacteria is catalysed by WecA, related in sequence to MraY and also an integral membrane protein [13]. The reaction catalysed by WecA is the reversible reaction of UDPGIcNAc with undecaprenyl phosphate to give undecaprenyldiphospho-GlcNAc and UMP. WecA also contains conserved aspartic acid residues that are important for catalysis: replacement of Asp-156 by Asn in E. coli WecA gives inactive enzyme, whereas replacement of Asp-90 or Asp-91 by Asn gives mutant enzymes with residual activity [13], though replacement of both residues gives inactive enzyme [14].

The first step of teichoic acid biosynthesis in Gram-positive bacteria, which is the same biochemical reaction as that catalysed by WecA, is catalysed by a related integral membrane protein TagO [15]. Interest in teichoic acid biosynthetic enzymes as antibacterial targets has been enhanced by the discovery that teichoic acid biosynthetic genes are essential for $S$. aureus nasal colonisation [16]. Campbell et al have shown that inhibition of TarO with tunicamycin sensitises methicillin-resistant $S$. aureus strains to beta-lactam antibiotics, implying a fundamental connection between teichoic acid biosynthesis and peptidoglycan assembly in S. aureus [17]. Other homologues in this phospho-sugar transferase family include a glucose-1-phosphate transferase WcaJ involved in colonic acid capsule biosynthesis in E. coli and C. crescentus [18], and transferase WcfS involved in B. fragilis capsular polysaccharide biosynthesis [19].

A further group of smaller 20-25 kDa phospho-sugar transferase enzymes containing a single transmembrane helix has also emerged, typified by C. jejuni PglC, which utilises a UDPdi- $N$-acetyl-bacillosamine substrate, involved in $N$-glycoconjugate biosynthesis [20]. The function of conserved amino acid residues in this family of enzymes has recently been investigated using site-directed mutagenesis [21]. The properties of the different phosphosugar transferases mentioned here are summarised in Table 1 
Table 1. Biochemical properties of phospho-sugar transferases

\section{Nucleoside natural product inhibitors of MraY and related enzymes}

Translocase MraY is the site of action for several nucleoside natural product antibiotics, including the mureidomycin/pacidamycin group of uridylpeptide antibiotics, the liposidomycin/caprazamycin group of liponucleoside antibiotics, and the muraymycin group of uridyldisaccharide antibiotics, which have been previously reviewed [2]. In recent years several studies have used synthetic chemistry to access analogues with higher chemical stability or altered antibacterial spectrum.

In the muraymycin series (see structures in Figure 4), Tanino et al have demonstrated that the esterified hydroxyleucine residue can be replaced by a long chain alkyl sidechain, giving synthetic analogues with good in vitro MraY inhibition activity $\left(\mathrm{IC}_{50} 0.33 \mu \mathrm{M}\right.$, compared with muraymycin $\mathrm{D} 2 \mathrm{IC}_{50} 0.01 \mu \mathrm{M}$ ) and antibacterial activity [22], and that the cyclic epicapreomycidine amino acid could be replaced by arginine, lysine or ornithine residues [23]. Using L-arginine in place of epicapreomycidine, Takeoka have further shown that the Cterminal amino acid can be removed while retaining full MraY inhibition activity, and enhanced antimicrobial activity against strains of Pseudomonas, and that an analogue containing two L-arginine residues shows MIC 4-8 $\mu \mathrm{g} / \mathrm{ml}$ against Pseudomonas strains [24]. Spork et al have synthesised a muraymycin analogue lacking the aminoribose sugar, which also retains MraY inhibition activity ( $\mathrm{IC}_{50} 2 \mu \mathrm{M}$ ) [25]. Ries et al have further shown that the $\omega$ guanylated fatty acid substituent found in the most active muraymycins is important for localisation of the antibiotic into the cytoplasmic membrane of the target organism [26]. These SAR data will help to inform the design of new analogues with improved antibacterial spectrum and pharmacokinetic properties. 


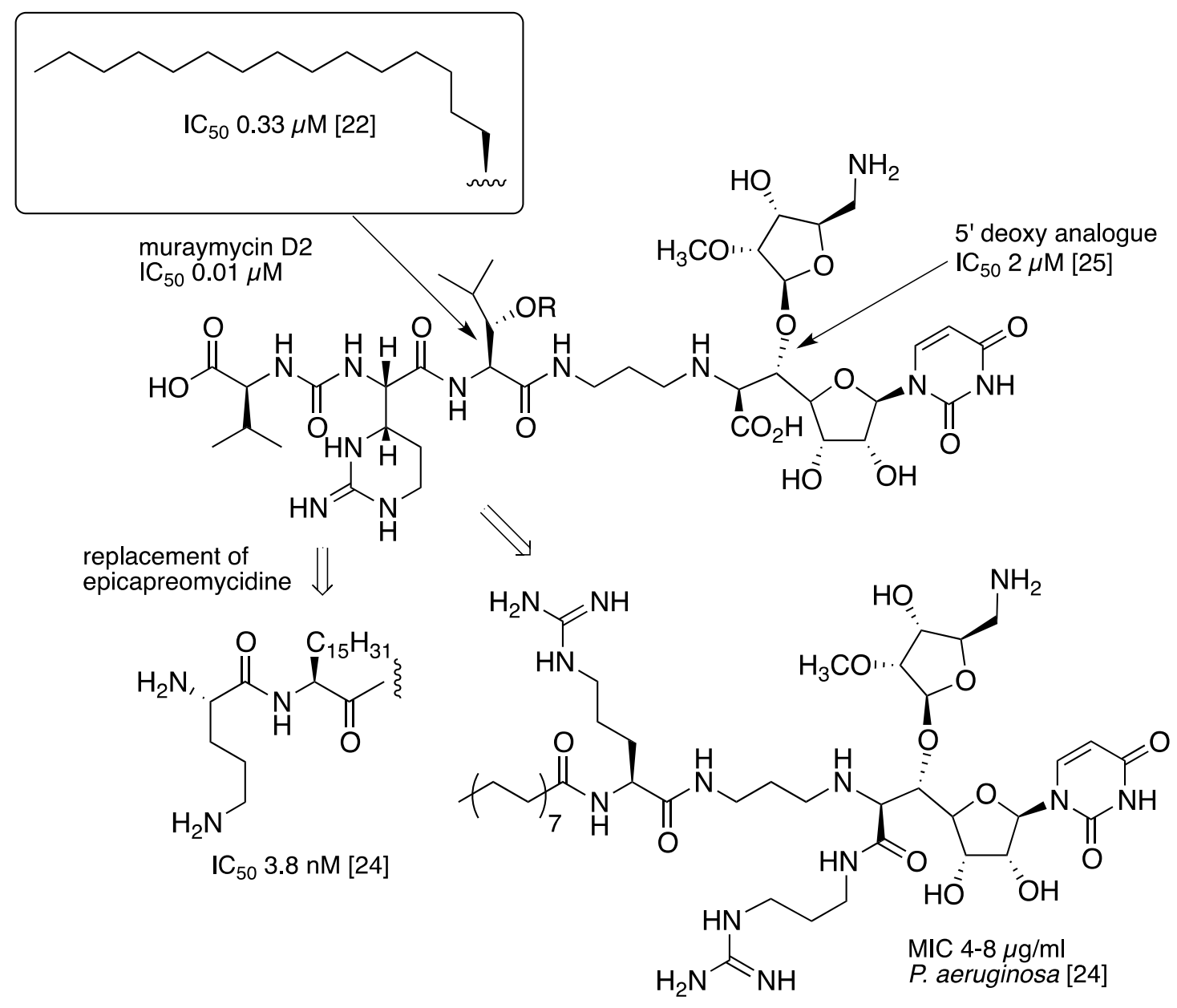

Figure 4. Recent structure-activity studies on muraymycin natural product antibiotics

In the caprazamycin series (see structures in Figure 5), an important discovery is that CPZEN-45, a semisynthetic caprazamycin derivative undergoing clinical trials for treatment of tuberculosis, preferentially targets transferase WecA in M. tuberculosis, rather than MraY [27]. CPZEN-45 retained activity against a strain of $B$. subtilis in which mraY was overexpressed, but lost activity against a strain in which transferase Tag0 was overexpressed, and was 8-fold more active in vitro against B. subtilis Tag0 (IC $5050 \mathrm{ng} / \mathrm{mL}$ ) than MraY (IC $50400 \mathrm{ng} / \mathrm{mL}$ ). In $M$. tuberculosis the homologue WecA is used in the biosynthesis of cell wall mycolyl arabinogalactan, and CPZEN-45 was found to inhibit M. tuberculosis WecA (IC $5040 \mathrm{ng} / \mathrm{mL}$ ) $>20$ fold more strongly than caprazamycin G [27]. In contrast, the muraymycin analogues noted above were highly selective for MraY inhibition over E. coli WecA [23]. The action of CPZEN-45 will prompt further interest in the selective inhibition of WecA and TagO. Farha et al have shown that TarO is inhibited by anti-platelet drug ticlopidine [28], and the same authors have synthesised a set of ticlopidine analogues as TarO inhibitors [29]. 
Ichikawa et al have synthesised analogues of caprazamycin in which the glutarate diester sidechain is replaced by a more stable alkyl chain, which retain strong biological activity [30]. Fer et al have also synthesised a series of triazole-containing analogues of the caprazamycins, which show $\mathrm{IC}_{50}$ values of 100-1000 $\mu \mathrm{M}$ against B. subtilis MraY, and show antibacterial activity against Staphylococcus aureus [31].

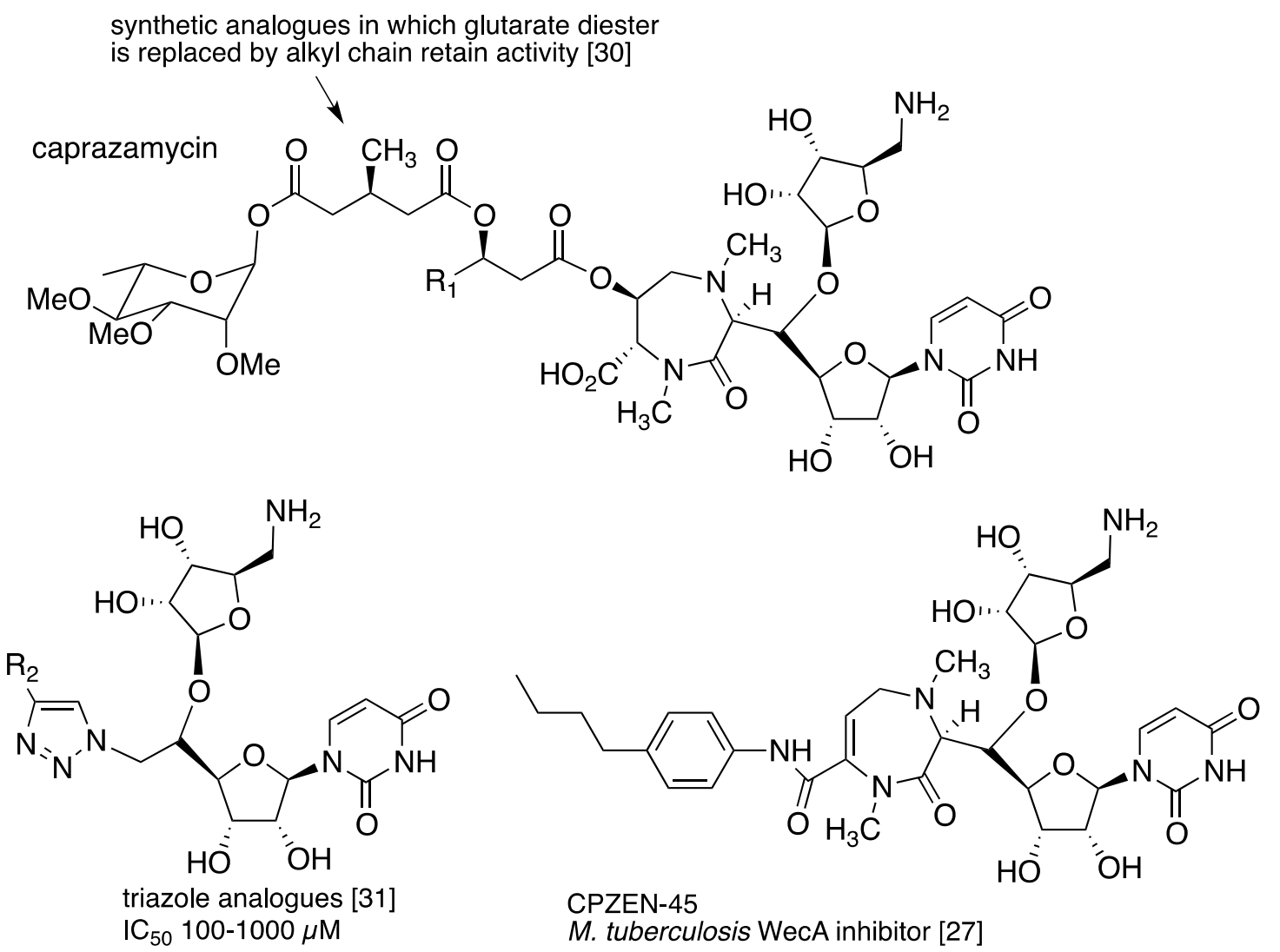

Figure 5. Recent structure-activity studies on the caprazamycin natural product antibiotics. $\mathrm{R}_{1}$ $=$ fatty acid sidechain; $\mathrm{R}_{2}=$ variable alkyl/aryl group.

In the pacidamycin series (see structures in Figure 6), Okamoto et al have completed a total synthesis of pacidamycin D [32], and have used the synthetic route to investigate structure-activity relationships in he N-terminal dipeptide chain [33], shown previously to be important for biological activity in the mureidomycin series [34]. The stereochemistry of the 2,3-diaminobutyric acid unit at C-2 was found to be important for both MraY inhibition and antibacterial activity, and meta-tyrosine was 180-fold more active for MraY inhibition than Ltyrosine in the N-terminal dipeptide [33]. Two new series of peptidyl-uridines whose structures are based upon mureidomycin A and tunicamycin have been synthesised as inhibitors of $C$. jejuni PglC, and selected compounds show $\mathrm{IC}_{50}$ values in the range 40-250 $\mu \mathrm{M}$ [35]. The biosynthetic pathway to both the pacidamycin [36-38] and caprazamycin [39] 
antibiotics has been elucidated, hence the use of biosynthetic engineering offers the possibility of generating modified uridyl peptide antibiotics via fermentation in the future.

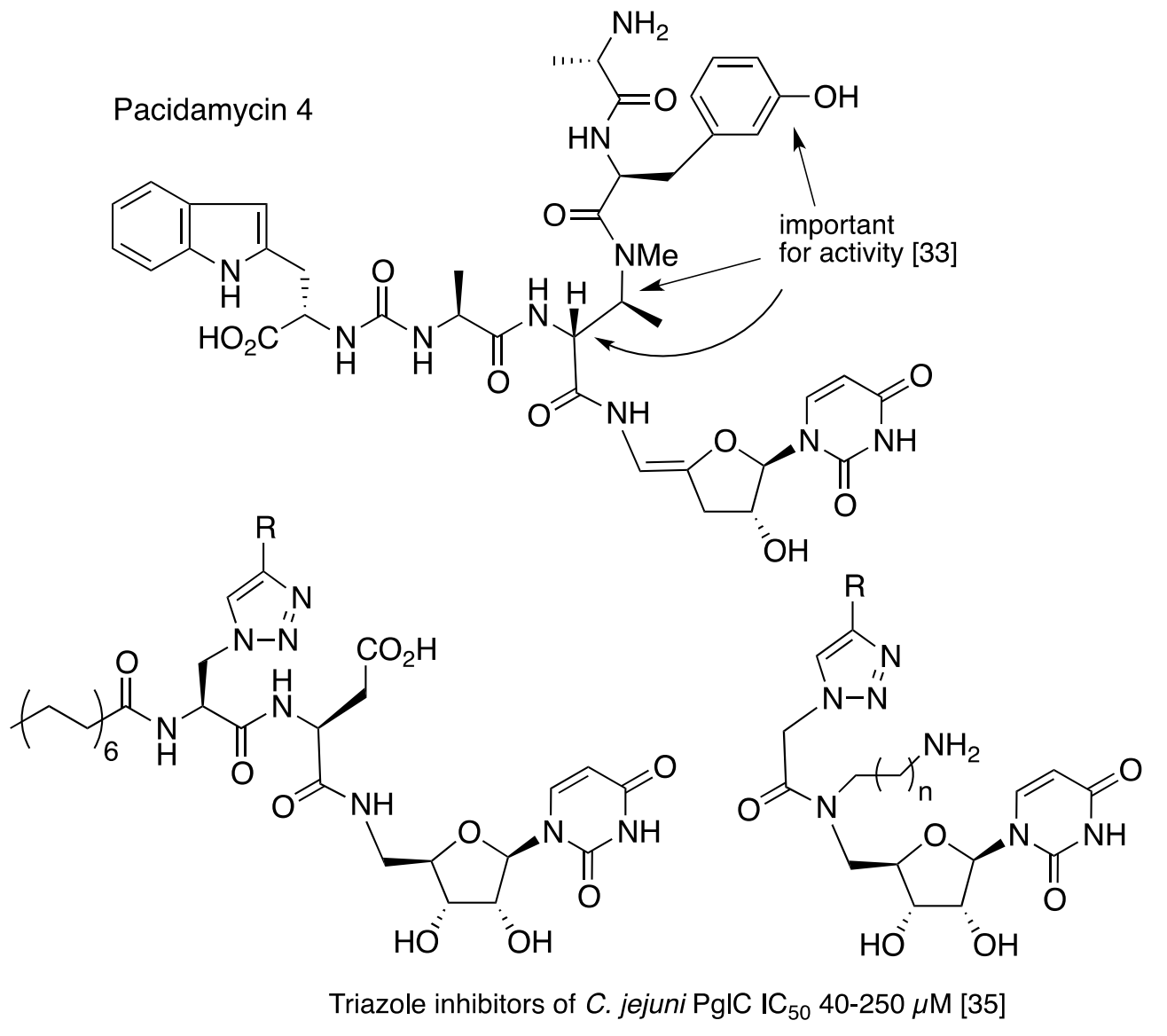

Figure 6. Recent structure-activity studies on the pacidamycin natural product antibiotics

The enzyme-bound conformation of MraY nucleoside natural pduct inhibitors is still uncertain. The presence of a uridine nucleoside moiety also found in the UDPMurNAcpentapeptide substrate suggests that the uridine group probably binds in the same site in both substrate and inhibitor complexes. Kinetic studies of the inhibition of E. coli MraY has shown that mureidomycin A and liposidomycin B are both slow-binding inhibitors, while tunicamycin is a reversible inhibitor $[40,41]$. Inhibition by mureidomycin A was found to be competitive with both UDPMurNAc-pentapeptide and undecaprenyl phosphate substrates, whereas liposidomycin B was competitive with undecaprenyl phosphate, but non-competitive with UDPMurNAc-pentapeptide [41].

\section{Other classes of MraY inhibitors}

Using a fluorescence-based assay, the National Cancer Institute Diversity Set $(\sim 2000$ compounds) has recently been screened for inhibitors of E. coli MraY, which has led to the identification of one further natural product inhibitor, michellamine B (IC50 $456 \mu \mathrm{M}$, see 
Figure 7), a plant naphthylloquinone alkaloid [42]. Docking studies against the A. aeolicus MraY structure suggests that this structure binds to a hydrophobic cleft in the protein structure, rather than to the enzyme active site [42]. The inhibition of MraY by chlorinated fluoresceins, identified by a previous MraY/MurG screen by Bristol-Myers Squibb [43], was also investigated, and phloxine B was identified as an MraY inhibitor ( $\mathrm{IC}_{50} 32 \mu \mathrm{M}$, see Figure 7), which is known to possess antibacterial activity [44]. Analogues of UDPMurNAc in which the diphosphate linkage was replaced by a $\beta$-ketophosphonate linkage have also been synthesised, but no inhibition against B. subtilis MraY was observed for two uridinecontaining analogues, while lipid-linked analogues showed $\mathrm{IC}_{50}$ 0.85-1.3 mM [45].<smiles></smiles>

michellamine B<smiles>O=C(O)c1c(Cl)c(Cl)c(Cl)c(Cl)c1-c1c2cc(Br)c(=O)c(Br)c-2oc2c(Br)c(O)c(Br)cc12</smiles>

phloxine B

Figure 7. Structures of other MraY inhibitors

\section{Interaction of MraY with bacteriophage $\phi X 174$ lysis protein $\mathrm{E}$}

In 2000, Bernhardt et al established using genetic methods that E. coli MraY is the site of action of the bacteriolytic lysis protein $\mathrm{E}$ of bacteriophage $\phi X 174$, a 91-amino acid protein that causes cell lysis of the host $E$. coli after phage particle assembly during the bacteriophage life cycle [46]. A host peptidyl-prolyl isomerase SlyD is also required for cell lysis, but variants of E (Epos) containing mutations R3H or L19F were isolated that do not require the slyD gene for cell lysis, and for these variants, the point mutation F288L in the mraY gene was found to cause resistance to E [46]. Mendel et al found that a synthetic peptide $\mathrm{E}_{\text {pep }}$ containing the Nterminal 37 amino acid transmembrane helix of E inhibits particulate MraY ( IC $_{50} 0.8 \mu \mathrm{M}$ ), but not detergent-solubilised MraY, and they proposed that E inhibits MraY via a site distant from the active site, likely to be a protein-protein interaction site between MraY and other cell division proteins [47]. 
A specific hypothesis for this protein-protein interaction site was recently proposed and investigated by Rodolis et al [48]. Construction of a helical wheel model for the transmembrane domain of E, and for helix 9 of MraY, resulted in the model shown in Figure 8A. In the model, Phe-288 of MraY that is implicated in the E-MraY interaction from genetic studies [46] is positioned close to the indole sidechains of Trp-4 and Trp-7 of E, which could form favourable $\pi-\pi$ stacking interactions with Phe-288 [48]. Also, the guanidine sidechain of Arg-3 of E could form an electrostatic interaction with neighbouring Glu-287 of MraY, which is conserved in bacterial MraY sequences.

Rodolis et al found that synthetic pentapeptides mimicking this RWxxW motif inhibited particulate MraY ( $\mathrm{IC}_{50} 210-590 \mu \mathrm{M}$ ), but showed no inhibition of F288L or E287A site-directed mutants of MraY, thereby verifying a specific interaction with these amino acid residues [48]. One synthetic dipeptide Arg-Trp-octyl ester was found to show antimicrobial activity against E. coli (MIC $31 \mu \mathrm{g} / \mathrm{mL}$ ), P. aeruginosa (MIC $40 \mu \mathrm{g} / \mathrm{mL}$ ), and S. aureus (MIC 30 $\mu \mathrm{g} / \mathrm{mL}$ ), and overexpression of the mraY gene in E. coli was found to raise the MIC value to $250 \mu \mathrm{g} / \mathrm{mL}$, implying that this is the site of antibacterial action [48]. Hence there appears to be a novel protein-protein interaction site in MraY, positioned on the outer face of the cytoplasmic membrane, which could be targeted by small molecule agents. The identity of the cellular protein-protein interaction partner for MraY is not known, and studies via yeast twohybrid technology are hindered by the reluctance of E. coli MraY to tolerate N- or C-terminal fusion tags, but there is evidence that MraY interacts with glycosyltransferase MurG, the next enzyme on the lipid cycle of peptidoglycan biosynthesis, and this interaction might mediate other interactions with a cell division complex [49].

Rodolis et al also observed that the structures of the nucleoside natural product MraY inhibitors contained elements of this RWxxW motif: muraymycin contains a epicapreomycidine analogue of arginine; while the pacidamycins contain a tryptophan at the C-terminus of the pentapeptide backbone, and a meta-tyrosine residue at the N-terminus [50]. They found that pacidamycin 1 showed 10-fold reduced inhibition against the F288L MraY mutant enzyme, implying some interaction of the antibiotic at this site, distant from the MraY active site [50]. Their rationalisation is that in order to access the MraY active site in vivo, they must first bind to the protein-protein interaction site, which leads to uptake of the inhibitor, probably via a protein conformational change, as shown in Figure 8B [50]. These observations might explain why simpler small molecule analogues of the nucleoside natural products that retain in vitro MraY activity often lose antibacterial potency, and why in general there is not a strong correlation between in vitro MraY inhibitory activity and antibacterial activity [3]. 


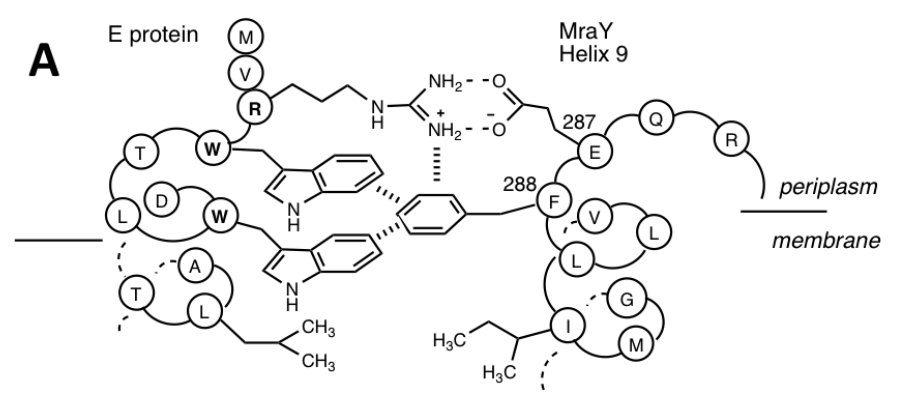

B

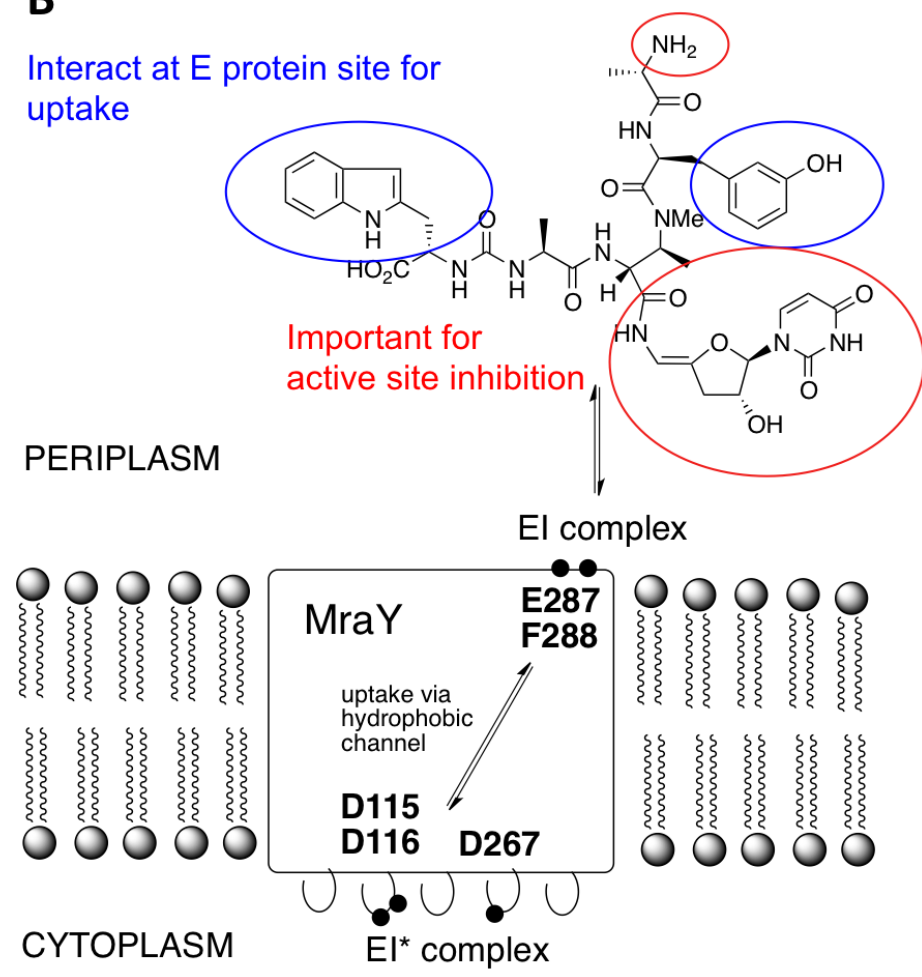

Figure 8. A. Interaction site between MraY and bacteriolytic protein E from bacteriophage $\phi X 174$, showing RWxxW motif. B. Elements of RWxxW motif present in pacidamycin structure, rationalisation of the role of different structural elements (adapted from reference $50)$.

\section{A novel site of action for cationic antimicrobial peptides containing Arg-Trp}

Interestingly, the RWxxW motif found in the lysis protein E is also observed close to the $\mathrm{N}$ - or $\mathrm{C}$-terminus of several naturally occurring cationic antimicrobial peptides, including indolicidin [51], cecropin [52], tritrpticin [53], lactoferricin B [54], and puroindoline A [55] as shown in Table 2. Many synthetic variants of cationic antimicrobial peptides have been generated by Hancock and co-workers, who have observed that Arg and Trp predominate in high activity peptide sequences [56-58], including that of clinical candidate MX226 (Omiganan) [57]. Other short synthetic peptides containing Arg-Trp have also been reported 
to show high levels of antimicrobial activity [59,60], even dipeptide derivatives based upon Trp-Arg [61].

Table 2. Cationic antimicrobial peptides containing Arg-Trp

Several cationic antimicrobial peptides containing the RWxxW motif were found to show 30-60\% inhibition of particulate E. coli MraY at $100 \mu \mathrm{g} / \mathrm{mL}$ concentration, indicating that these antibacterial peptides can target this site. Overexpression of the mraY gene in E. coli was found unusually to reduce the MIC value of some cationic antimicrobial peptides, the rationalisation being that the interaction with MraY may promote the insertion of the antibacterial peptides into the cytoplasmic membrane [48]. Hence it appears that this sequence motif is used by some cationic antimicrobial peptides in order to assist uptake into bacterial cells. Studies over many years on antimicrobial peptides has indicated that there are multiple sites of action for these compounds, due to the low incidence of resistance via genetic mutation [62], hence this appears to be a new site of interaction on the cell surface for antimicrobial peptides. Wenzel et al have also recently reported that treatment of $B$. subtilis with hexapeptide RWRWRW causes effects on cell wall biosynthesis, and the release of extrinsic membrane protein MurG from the cytoplasmic membrane [63]. Since MurG is known to interact with MraY [49], this effect might be caused by an initial binding to MraY, displacing MurG.

There is a question of whether this interaction site would only be an antibacterial target for E. coli, since Phe-288 is only conserved in MraY sequences from Enterobacteriaceae, and is replaced by Ile in Pseudomonas aeruginosa [48]. However, interestingly, the RWoct dipeptide derivative has antimicrobial activity against E. coli and P. aeruginosa [48]. In the crystal structure of A. aeolicus MraY [8], close to Phe-288 there are three other Phe residues forming a hydrophobic pocket, that may assist in the protein-protein interaction site, that are conserved in other Gram-negative MraY sequences. We note in Table 2 that many of the antibacterial peptides containing Arg-Trp sequences show activity against P. aeruginosa as well as E. coli.

Some protein E sequences found in other G4-like microviridae bacteriophages contain a Glu-His-Trp sequence in place of Arg-Trp, and a synthetic EHWGGG peptide was found to inhibit E. coli particulate MraY [48]. There are two reports of synthetically modified Trp-His and His-Arg dipeptides that show antimicrobial activity, although only weak activity against $E$. coli and P. aeruginosa, that might be connected with this observation $[64,65]$. 


\section{Summary and prospects}

The continued emergence of new antibiotic-resistant bacterial pathogens with limited therapies underlines the need to identify novel targets for antibacterial action, and bacterial peptidoglycan biosynthesis remains a well-proven target for antibacterial action [66]. There has been increased research interest in the MraY family of phospho-sugar transferase enzymes in recent years, due to: the existence of several classes of nucleotide natural product antibiotics that target MraY [2]; the discovery that anti-TB drug candidate CPZEN-45 inhibits M. tuberculosis WecA rather than MraY [27]; and the existence of related phospho-sugar transferases involved in lipid-linked polysaccharide and glycoprotein biosynthesis pathways, for which selective inhibitors would be of great interest. The structure determination of $A$. aeolicus MraY [8] opens up possibilities for structure-based drug design against MraY and related enzymes. Although protein biochemistry for this group of integral membrane proteins remains very challenging, Bernard and co-workers have shown that recombinant MraY enzymes can be produced in good yield via cell-free protein expression [64], and can be reconstituted in nanodisc synthetic bilayers [68], offering an alternative to conventional protein expression technology. The discovery that Nature has also targeted MraY via a bacteriolytic lysis protein $\mathrm{E}$ and via antimicrobial peptides of diverse origins [48] suggests that it may be a relatively "weak spot" for antibacterial action that could ultimately yield new antimicrobial agents, in spite of the inherent practical difficulties.

Acknowledgements. Research in the author's laboratory was supported by a National Science Foundation PhD scholarship to M.R., Medical Research Council grant G1100127, and the University of Warwick.

\section{References}

1. Bouhss, A.; Trunkfield, A. E.; Bugg, T. D. H.; Mengin-Lecreulx, D. FEMS Microbiol. Rev. 2008, 32, 208-233

2. Winn, M.; Goss, R. J. M.; Kimura, K.; Bugg, T. D. H. Nat. Prod. Rep. 2010, 27, 279-304

3. Bugg, T.D.H.; Lloyd, A.J.; Roper, D.I. Infect. Disorders Drug Targets 2006, 2, 85-106.

4. Bouhss, A. ; Mengin-Lecreulx, D. ; Le Beller, D. ; van Heijenoort, J. Mol. Microbiol., 1999, 34, 576-585.

5. Pless, D.D.; Neuhaus, F.C. J. Biol. Chem., 1973, 248, 1568-1576. 
6. Lloyd, A. J.; Brandish, P. E.; Gilbey, A. M.; Bugg, T. D. H. J. Bacteriol. 2004, 186, 1747-1757

7. Al-Dabbagh, B.; Henry, X.; El Ghachi, M.; Auger, G.; Blanot, D.; Parquet, C.; Mengin-Lecreulx, D.; Bouhss, A. Biochemistry 2008, 47, 8919-8928.

8. Chung, B. C.; Zhao, J.; Gillespie, R. A.; Kwon, D.; Guan, Z.; Hong, J.; Zhou, P.; Lee, S. Science 2013, 341, 1012-1016.

9. Matte, A.; Tari, L.W.; Delbaere, L.T.J. Structure 1998, 6, 413-419.

10. Hargrove, A.E.; Nieto, S.; Zhang, T.; Sessler, J.L.; Anslyn, E.V. Chem. Rev. 2011, 111, 66036782.

11. Fahlbusch, T.; Frank, M.; Schatz, J.; Schmaderer, M. Eur. J. Org. Chem. 2006, 8, 1899-1903.

12. Lu, Q-S.; Dong, L.; Zhang, J.; Li, J.; Huang, Y.; Qin, S.; Hu, C-W.; Yu, X-Q. Org. Lett. 2009, 11, 669-672.

13. Lehrer, J.; Vigeant, K.A.; Tatar, L.D.; Valvano, M.A. J. Bacteriol. 2007, 189, 2618-2628.

14. Amer, A.O.; Valvano, M.A. Microbiology 2002, 148, 571-582.

15. Soldo, B.; Lazarevic, V.; Karamata, D. Microbiology 2002, 148, 2079-2087.

16. Weidenmaier C.; Kokai-Kun, J.F.; Kristian, S.A.; Chanturiya, T.; Kalbacher, H.; Gross, M.; Nicholson, G.; Neumeister, B.; Mond, J.J.; Peschel, A. Nature Medicine 2004, 10, 243-245.

17. Campbell, J.; Singh, A.K.; Santa Maria Jr., J.P.; Kim, Y.; Brown, S.; Swoboda, J.G.; Mylonakis, E.; Wilkinson, B.J.; Walker S. ACS Chem. Biol. 2011, 6, 106-116.

18. Patel, K.B.; Toh, E.; Fernandez, X.B.; Hanuszkiewicz, A.; Hardy, G.G.; Brun, Y.V.; Bernards, M.A.; Valvano, M.A. J. Bacteriol. 2012, 194, 2646-2657.

19. Mostafavi, A.Z.; Troutman, J.M. Biochemistry 2013, 52, 1939-1949.

20. Glover, K.J.; Weerapana, E.; Chen, M.M.; Imperiali, B. Biochemistry 2006, 45, 5343-5350.

21. Lukose, V.; Luo, L.; Kozakov, D.; Vajda, S.Allen, K.N.; Imperiali, B. Biochemistry 2015, 54, 7326-7334.

22. Tanino T.; Ichikawa, S.; Al-Dabbagh, B.; Bouhss, A.; Oyama, H.; Matsuda, A. ACS Med. Chem. Lett. 2010, 1, 258-262.

23. Tanino T.; Al-Dabbagh, B.; Mengin-Lecreulx, D.; Bouhss, A.; Oyama, H.; Ichikawa, S.; Matsuda, A. J. Med. Chem. 2011, 54, 8421-8439.

24. Takeoka, Y.; Tanino T.; Sekiguchi, M.; Yonezawa, S.; Sakagami, M.; Takahashi, F.; Togame, H.; Tanaka, Y.; Takemoto, H.; Ichikawa, S.; Matsuda, A. ACS Med. Chem. Lett. 2014, 5, 556560.

25. Spork, A.P.; Büschleb, M.; Ries, O.; Wiegmann, D.; Boettcher, S.; Mihalyi, A.; Bugg, T.D.H.;

Ducho, C. Chem. Eur. J. 2014, 20, 15292-15297.

26. Ries, O.; Carnarius, C.; Steinem, C.; Ducho, C. Med. Chem. Comm. 2015, 6, 879-886. 
27. Ishizaki, Y.; Hayashi, C.; Inoue, K.; Igarashi, M.; Takahashi, Y.; Pujari, V.; Crick, D.C.; Brennan, P.J.; Nomoto, A. J. Biol. Chem. 2013, 288, 30309-30319.

28. Farha, M.A.; Leung, A.; Sewell, E.W.; D’Elia, M.A.; Allison, S.E.; Ejim, L.; Pereira, P.M.; Pinho, M.G.; Wright, G.D.; Brown, E.D. ACS Chem. Biol. 2013, 8, 226-233.

29. Farha, M.A.; Koteva, K.; Gale, R.T.; Sewell, E.W.; Wright, G.D.; Brown, E.D. Bioorg. Med. Chem. Lett. 2014, 24, 905-910.

30. Ichikawa, S.; Yamaguchi, M.; Hsuan, L.S.; Kato, Y.; Matsuda, A. ACS Infect. Dis. 2015, 1, 151156.

31. Fer, M.J.; Bouhss, A.; Patrao, M.; Le Corre, L.; Pietrancosta, N.; Amoroso, A.; Joris, B.; Mengin-Lecreulx, D.; Calvet-Vitale, S.; Gravier-Pelletier, C. Org. Biomol. Chem. 2015, 13, 7193-7222.

32. Okamoto, K.; Sakagami, M.; Feng, F.; Togame, H.; Takemoto, H.; Ichikawa, S.; Matsuda, A. Org. Lett. 2011, 13, 5240-5243.

33. Okamoto, K.; Sakagami, M.; Feng, F.; Takahashi, F.; Uotani, K.; Togame, H.; Takemoto, H.; Ichikawa, S.; Matsuda, A. Bioorg. Med. Chem. Lett. 2012, 22, 4810-4815.

34. Howard, N.I.; Bugg, T.D.H. Bioorg. Med. Chem. 2003, 11, 3083-3099.

35. Walvoort, M.T.C.; Lukose, V.; Imperiali, B. Chem. Eur. J. 2015, 22, 3856-3864.

36. Rackham, E.J.; Grüschow, S.; Ragab, A.E.; Dickens, S.; Goss, R.J. ChemBioChem 2010, 11, 1700-1709.

37. Zhang, W.; Ostash, B.; Walsh, C.T. Proc. Natl. Acad. Sci. USA 2010, 107, 16828-16833.

38. Zhang, W.; Ntai, I.; Bolla, M.L.; Malcolmson, S.J.; Kahne, D.; Kelleher, N.L.; Walsh, C.T. J. Am. Chem. Soc. 2011, 133, 5240-5243.

39. Kaysser, L.; Lutsch, L.; Siebenberg, S.; Wemakor, E.; Kammerer, B.; Gust, B. J. Biol. Chem. 2009, 284, 14987-14996.

40. Brandish, P.E.; Burnham, M.; Lonsdale, J.T.; Southgate, R.; Inukai, M.; Bugg, T.D.H. J. Biol. Chem. 1996, 271, 7609-7614.

41. Brandish, P.E.; Kimura, K.; Inukai, M.; Southgate, R.; Lonsdale, J.T.; Bugg, T.D.H. Antimicrob. Agents Chemother. 1996, 40, 1640-1644.

42. Mihalyi, A.; Jamshidi, S.; Slikas, J.; Bugg, T.D.H. Bioorg. Med. Chem. 2014, 22, 4566-4571.

43. Zawadzke, L. E.; Wu, P.; Cook, L.; Fan, L.; Casperson, M.; Kishnani, M.; Calambur, D.; Hofstead, S. J.; Padmanabha, R. Anal. Biochem. 2003, 314, 243-252

44. Rasooly A.; Weisz, A. Antimicrob. Agents Chemother. 2002, 46, 3650-3653.

45. Auberger, N.; Frian, R.; Al-Dabbagh, B.; Bouhss, A.; Crouvoisier, M.; Gravier-Pelletier, C.; Le Merrer, Y. Org. Biomol. Chem. 2011, 9, 8301-8312. 
46. Bernhardt, T.G.; Roof, W.D.; Young, R. Proc. Natl. Acad. Sci. USA 2000, 97, 4297-4302.

47. Mendel, S.; Holbourn, J.M.; Schouten, J.A.; Bugg, T.D.H. Microbiology 2006,152, 2959-2967

48. Rodolis, M. T.; Mihalyi, A.; O’Reilly, A.; Slikas, J.; Roper, D. I.; Hancock, R. E. M.; Bugg, T. D. H. ChemBioChem 2014, 15, 1300-1308.

49. Mohammadi, T.; Karczmarek, A.; Crouvoisier, M.; Bouhss, A.; Mengin-Lecreulx, D.; Den Blaauwen, T. Mol. Microbiol. 2007, 65, 1106-1121.

50. Rodolis, M.T.; Mihalyi, A.; Ducho, C.; Eitel, K.; Gust, B.; Goss, R.J.M.; Bugg, T.D.H. Chem Commun. 2014, 50, 13023-13025.

51. Selsted, M.E.; Novotny, M.J.; Morris, W.L.; Tang, Y-Q.; Smith, W.; Cullor, J.S. J. Biol. Chem. 1992, 267, 4292-4295.

52. Oh, D.; Shin, S.Y.; Lee, S.; Kang, J.H.; Kim, S.D.; Ryu, P.D.; Hahn, K-S.; Kim, Y. Biochemistry 2000, 39, 11855-11864.

53. Lawyer, C.; Pai, S.; Watabe, M.; Borgia, P.; Mashimo, T.; Eagleton, L.; Watabe, K. FEBS Lett. 1996, 390, 95-98.

54. Strøm, M.B.; Svendsen, J.S.; Rekdal, Ø. J. Pept. Res. 2000, 56, 265-274.

55. Jing, W.; Demcoe, A.R.; Vogel, H.J. J. Bacteriol. 2003, 185, 4938-47.

56. Hilpert, K.; Volkmer-Engert, R.; Walter, T.; Hancock, R.E.W. Nat. Biotechnol. 2005, 23, 1008-1012.

57. Cherkasov, A.; Hilpert, K.; Jenssen, H.; Fjell, C.D.; Waldbrook, S.C.; Mullaly, S.C.; Volkmer, R.; Hancock, R.E.W. ACS Chem Biol 2009, 4, 65-74.

58. Fjell, C.D.; Jenssen, H.; Hilpert, K.; Cheung, W.A.; Panté, N.; Hancock, R.E.W. Cherkasov, A. J. Med. Chem. 2009, 52, 2006-2015.

59. Blondelle, S.E.; Takahashi, E.; Dinh, K.T.; Houghten, R.A. J. Appl. Bacteriol. 1995, 78, 39-46.

60. Liu, Z.; Brady, A.; Young, A.; Rasimick, B.; Chen, K.; Zhou, C.; Kallenbach, N.R. Antimicrob. Agents Chemother. 2007, 51, 597-603.

61. Haug, B.E.; Stensen, W.; Stiberg, T.; Svendsen, J.S. J. Med. Chem. 2004, 47, 4159-4152.

62. Hancock, R.E.W.; Sahl, H-G. Nat. Biotechnol. 2006, 24, 1551-1557.

63. Wenzel, M.; Chiriac, A.I.; Otto, A.; Zweytick, D.; May, C.; Schumacher, C.; Gust, R.; Albada, H.B.; Penkova, M.; Krämer, U.; Erdmann, R.; Metzler-Nolte, N.; Straus, S.K.; Bremer, E.; Becher, D.; Brötz-Oesterhelt, H.; Sahl, H-G.; Bandow, J.E. Proc. Natl. Acad. Sci USA, 2014, 111, E1409-E1418.

64. Sharma, R.K.; Reddy, R.P.; Tegge, W.; Jain, R. J. Med. Chem. 2009, 52, 7421-7431.

65. Mahindra, A.; Sharma, K.K.; Rathore, D.; Khan, S.I.; Jacob, M.R.; Jain, R. Med. Chem. Commun. 2014, 5, 671-676. 
66. Bugg, T. D. H.; Braddick, D.; Dowson, C. G.; Roper, D. I. Trends Biotechnol. 2011, 29, 167173

67. Ma, Y.; Münch, D.; Schneider, T.; Sahl, H-G.; Bouhss, A.; Ghoshdastider, U.; Wang, J.; Dötsch, V.; Wang, X.; Bernhard, F. J. Biol. Chem. 2011, 286, 38844-38853.

68. Henrich, E.; Ma, Y.; Engels, I.; Münch, D.; Otten, C.; Schneider, T.; Henrichfreise, B.; Sahl, HG.; Dötsch, V.; Bernhard, F. J. Biol. Chem. 2016, 291, 2535-2346.

69. Verdonk, M.L.; Berdini, V.; Hartshorn, M.J.; Mooij, W.T.; Murray, C.W.; Taylor, R.D.; Watson P. J. Chem. Inf. Comput. Sci. 2004, 44, 793-806.

70. DeLano, W.L. The PYMOL User's Manual, DeLano Scientific, Palo Alto, CA, 2002. 
Table 1. Properties and inhibitors of bacterial phospho-sugar transferases

\begin{tabular}{|c|c|c|c|c|}
\hline Enzyme & Organism & $\begin{array}{l}\text { Nucleotide-sugar substrate } \\
\text { [Pathway] }\end{array}$ & $\begin{array}{l}\text { Active site } \\
\text { residues }\end{array}$ & Inhibitors \\
\hline MraY & $\begin{array}{l}\text { E. coli } \\
\text { B. subtilis } \\
\text { A. aeolicus }\end{array}$ & $\begin{array}{l}\text { UDPMurNAc-pentapeptide } \\
\text { [peptidoglycan biosynthesis] }\end{array}$ & $\begin{array}{l}\text { Asp-115 } \\
\text { Asp-116 } \\
\text { Asp-267 }\end{array}$ & $\begin{array}{l}\text { Tunicamycin } \\
\text { Mureidomycins/pacidamycins } \\
\text { Liposidomycins/caprazamycins } \\
\text { Muraymycins } \\
\text { Capuramycins } \\
\phi X 174 \text { E protein }\end{array}$ \\
\hline WecA & $\begin{array}{l}\text { E. coli } \\
\text { M. tuberculosis }\end{array}$ & $\begin{array}{l}\text { UDPGlcNAc } \\
\text { [lipopolysaccharide } \\
\text { biosynthesis] }\end{array}$ & $\begin{array}{l}\text { Asp-90 } \\
\text { Asp-91 } \\
\text { Asp-156 }\end{array}$ & $\begin{array}{l}\text { Tunicamycin } \\
\text { CPZEN-45 }\end{array}$ \\
\hline Tag0 & $\begin{array}{l}\text { Gram-positive } \\
\text { Bacteria }\end{array}$ & $\begin{array}{l}\text { UDPGlcNAc } \\
\text { [teichoic acid biosynthesis] }\end{array}$ & & $\begin{array}{l}\text { Tunicamycin } \\
\text { Ticlopidine }\end{array}$ \\
\hline WcaJ & E. coli & $\begin{array}{l}\text { UDP-Glucose } \\
\text { [colonic acid capsule } \\
\text { biosynthesis] }\end{array}$ & & \\
\hline WcfS & B. fragilis & $\begin{array}{l}\text { UDP-acetamido-4-amino-6- } \\
\text { deoxy-galactose } \\
\text { [Capsular polysaccharide } \\
\text { biosynthesis] }\end{array}$ & & \\
\hline PglC & C. jejuni & $\begin{array}{l}\text { UDP-di-N-acetyl- } \\
\text { bacillosamine } \\
\text { [N-glycoconjugate } \\
\text { biosynthesis] }\end{array}$ & & Peptidyl-uridine analogues \\
\hline
\end{tabular}


Table 2. Cationic antimicrobial peptides containing sequences related to the Arg-Trp-X-X-Trp sequence motif (highlighted in bold). Peptide sequences reported from N-terminus except where indicated. N, N-terminus; C, Cterminus; NR, not reported.

\begin{tabular}{|c|c|c|c|c|c|}
\hline \multirow{2}{*}{ Peptide } & \multirow{2}{*}{ Sequence } & \multicolumn{2}{|c|}{ MIC values $(\mu \mathrm{g} / \mathrm{ml})$} & \multirow{2}{*}{$\begin{array}{l}\text { MraY inhibition } \\
\mathrm{IC}_{50}(\mu \mathrm{M})\end{array}$} & \multirow[t]{2}{*}{ Ref } \\
\hline & & E. coli & P. aeruginosa & & \\
\hline $\begin{array}{l}\text { фX174 E peptide } \\
\text { Indolicidin } \\
\text { Kai47 } \\
\text { Kai50 } \\
\text { MX226 } \\
\text { Sub6 } \\
\text { 1002 } \\
\text { Bac8c } \\
\text { cecropin } \\
\text { tritrpticin } \\
\text { lactoferricin B } \\
\text { puroindoline A } \\
\text { Short Arg-Trp } \\
\text { peptides } \\
\text { RWxxW mimics }\end{array}$ & $\begin{array}{l}\text { MVRWTLWDTLAFLLL } \\
\text { C-RRWPWWPWKWPLI } \\
\text { C-KRWKWWRFKWKIF } \\
\text { C-RRWWRWWRWKWRLI } \\
\text { C-KRRWPWWPWRLI } \\
\text { C-RWWKIWVIRWWR } \\
\text { N-VQRWLIVWRIRK } \\
\text { N-RRWIVWIR } \\
\text { KWKLFKKIEK } \\
\text { VRRFPWWWPFLRR } \\
\text { EKCRRWQWRMKKLG } \\
\text { GKWWKWWRWTVPF } \\
\text { ACRRWWCF } \\
\text { RWRWRWRW } \\
\text { RWGLW } \\
\text { RWGGW } \\
\text { GWGLW } \\
\text { RGGLW } \\
\text { RWGLG } \\
\text { GWoCt } \\
\text { RWOCt }\end{array}$ & $\begin{array}{l}\text { lytic } \\
12 \cdot 5-25 \\
31 \\
31 \\
38 \\
4-16 \\
8 \\
2 \\
1.0 \\
20 \\
24 \\
7 \mu \mathrm{M} \\
20 \\
10 \mu \mathrm{M} \\
- \\
- \\
- \\
- \\
- \\
- \\
31\end{array}$ & $\begin{array}{l}- \\
2-16 \\
N R \\
N R \\
19-76 \\
31 \\
\text { NR } \\
8 \\
5-6 \\
1-8 \\
\text { NR } \\
\text { NR } \\
45 \\
\text { NR } \\
- \\
- \\
- \\
- \\
- \\
- \\
40\end{array}$ & $\begin{array}{l}590 \\
233 \\
209 \\
210 \\
274 \\
790 \\
>1000\end{array}$ & $\begin{array}{l}{[47]} \\
{[51]} \\
{[58]} \\
{[58]} \\
{[57]} \\
{[56]} \\
{[48]} \\
{[56]} \\
{[52]} \\
{[53]} \\
{[54]} \\
{[55]} \\
{[59]} \\
{[60]} \\
{[48]} \\
{[48]} \\
{[48]} \\
{[48]} \\
{[48]} \\
{[48]} \\
{[48]}\end{array}$ \\
\hline
\end{tabular}



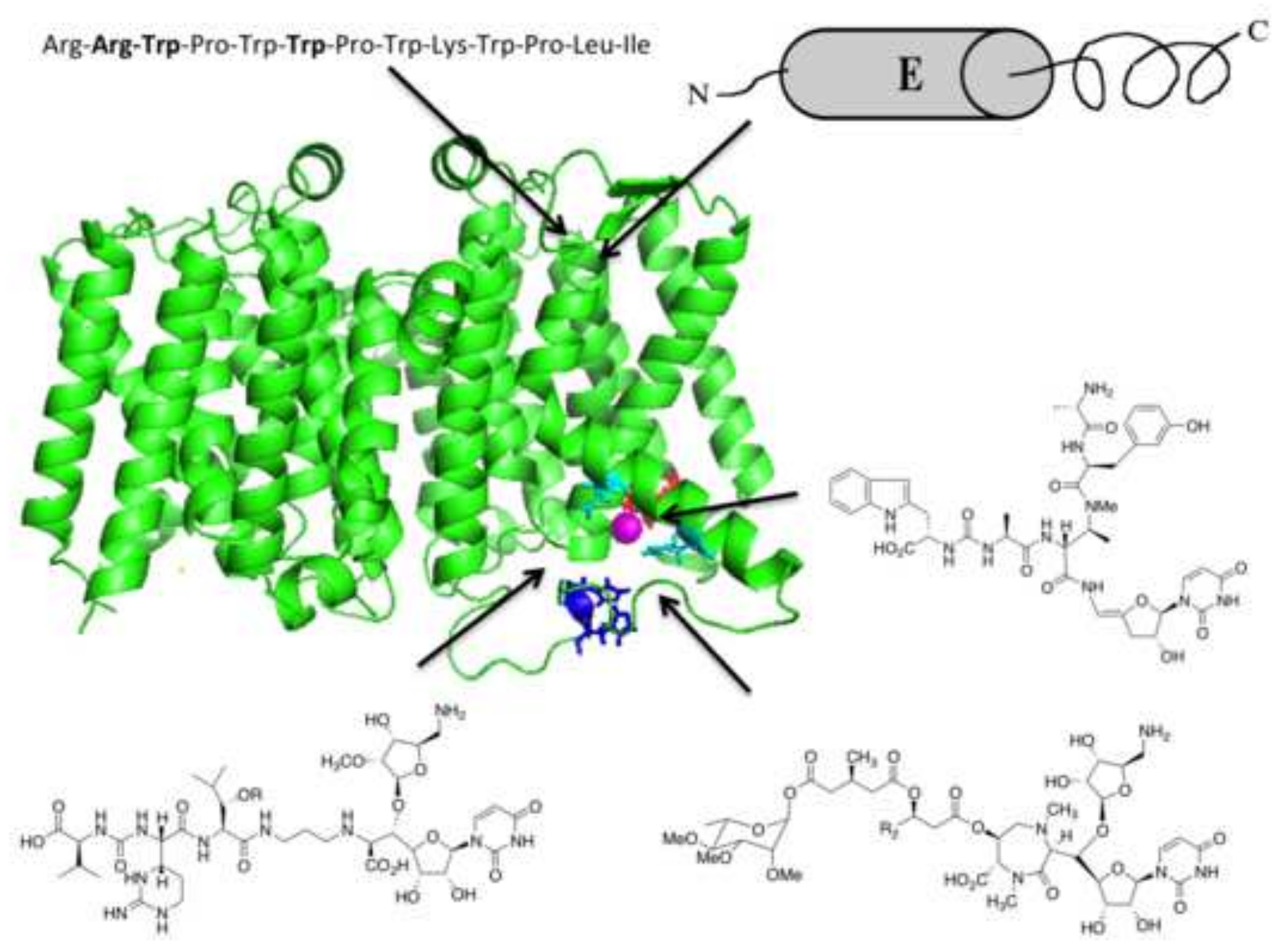